\title{
How Should the Value Relevance Research Employ Book Value of Equity?
}

\author{
Melik ERTUĞRUL (iD) a \\ a Istinye University, Department of Economics, Istanbul, Turkey. melik.ertugrul@istinye.edu.tr

\begin{tabular}{ll}
\hline ARTICLE INFO & ABSTRACT \\
\hline $\begin{array}{l}\text { Keywords: } \\
\text { Mechanical interdependency }\end{array}$ & $\begin{array}{l}\text { Purpose - This study analyses how the mechanical interdependency affects the value relevance } \\
\text { inferences by considering the Price Model. } \\
\text { Design/methodology/approach - As the Price Model employs reported earnings together with } \\
\text { book value of equity (BVE), it induces a mechanical interdependency since earnings are partially } \\
\text { integrated to BVE via the net income available to owners of parent item. We suggest researchers }\end{array}$ \\
$\begin{array}{l}\text { Value relevance } \\
\text { subtract this item from BVE prior to analyses. We perform analyses by employing the Price Model } \\
\text { with the unadjusted (or reported) version BVE and the Price Model with the adjusted version of }\end{array}$ \\
$\begin{array}{l}\text { BVE. } \\
\text { Received 28 April 2020 }\end{array}$ \\
$\begin{array}{l}\text { Findings - The Price Model with unadjusted BVE figures generates value irrelevant earnings } \\
\text { figures which is contrary to expectations. However, as per our suggestion, after adjusting BVE for } \\
\text { the net income available to owners of parent item, earnings become value relevant. }\end{array}$ \\
Accepted 20 June 2020 & $\begin{array}{l}\text { Discussion - Although no mechanical interdependency does exist at conventional statistical } \\
\text { significance levels, researchers should know data they work in value relevance studies as both } \\
\text { independent variables of the Price Model is partially integrated which may yield incorrect value } \\
\text { relevance inferences. }\end{array}$
\end{tabular}

\section{Introduction}

Beginning from the ground-breaking studies of Miller and Modigliani (1966), Ball and Brown (1968), and Beaver (1968), the value relevance (VR) research has come into the scene of the accounting academia. VR is one of the subsets of empirical accounting research analysing financial reporting quality and it is a common subgroup of the Capital Markets-Based Accounting Research classifications of both Beaver (2002) and Kothari (2001). The extant literature defines VR in slightly different manners; the fourth interpretation of Francis and Schipper (1999) is the commonly accepted definition (Ertuğrul, 2019a). That interpretation underscores that the statistically significant association between a financial reporting item and capital market figures is a proxy for VR. Barth, Beaver, and Landsman (2001) highlight that VR provides a convenient research setting for the joint analysis of reliability and relevance criteria of financial reporting information.

Models used to test VR rely on the Price Model of Ohlson (1995) and the Return Model of Easton and Harris (1991). Depending on the research question of the researcher, their use may be preferable. For instance, if a researcher aims to shed light on VR of stock variables such as book value of equity (BVE), the use of the former becomes convenient as the latter is generally employed to test VR of flow variables such as earnings (Easton \& Harris, 1991). The former also allows for testing VR of flow variables. Earnings-based valuation models and balance sheet-based valuation models are considered substitutes by the literature; however, they may be considered complementary as markets are not perfect (Burgstahler \& Dichev, 1997). The use of the Price Model provides a complementary valuation framework from the perspective of Burgstahler and Dichev (1997). Furthermore, the use of both models also depends on the econometrical concerns of the researcher. In the Return Model, although White specification is less problematic (Easton, 1999), earnings response coefficients are more biased (Kothari \& Zimmerman, 1995) and earnings may not summarize certain events that have already been incorporated in returns (Easton, Harris, \& Ohlson, 1992). Furthermore, as the Return Model yields lower $\mathrm{R}^{2}$ figures, earnings alone may be an insufficient summary of financial 
reporting information (Easton, 1999) which makes researchers conclude incorrect inferences (Kothari \& Zimmerman, 1995). On the other hand, in the Price Model, since the stock variable, BVE, captures "all accounting measures of change in value since the firm came into existence" (Easton, 1999, p. 401), this Model is better for summarizing financial reporting information and it yield higher $\mathrm{R}^{2}$ figures. Although earnings response coefficients are more biased in the Price Model (Kothari \& Zimmerman, 1995), it is criticized as it generates inflated $\mathrm{R}^{2}$ figures due to the scale effect problem, the common mitigation technique of which is scaling each variable by the same item (Brown, Lo, \& Lys, 1999; Kothari \& Zimmerman, 1995). All in all, both models have certain advantages and disadvantages, and they provide beneficial insights from different perspectives.

According to the recent literature review of Ertuğrul (2019a), the literature majorly employs the Price Model to test VR of financial reporting items. This Model jointly reveals the association between i) price and BVE, and ii) price and earnings. The logic behind this Model is the clean surplus relation between the income statement and the balance sheet. Depending on her/his research objective, a researcher may add other stock (such as goodwill, minority interests, or certain intangibles) and flow (such as other comprehensive income or other reconciliation items) variables to the Model. The fundamental and prevalently used version of this Model is shown in Equation (1).

$\mathrm{P}_{\mathrm{i}, \mathrm{t}+1}=\beta_{0}+\beta_{1} \times \mathrm{BVE}_{\mathrm{i}, \mathrm{t}}+\beta_{2} \times \mathrm{E}_{\mathrm{i}, \mathrm{t}}$

where $i, t, P, B V E$, and E represent firm, year, price, book value of equity, and earnings, respectively. BVE is reported common shareholder's equity while earnings are bottom-line net income figures. In Equation (1), there is a mechanical interdependency between independent variables since BVE includes a considerable portion of the current net income figure. Even more, in case of no minority interests, BVE directly includes current net income as a whole. The most common approach of detecting multicollinearity (or mechanical interdependencies) is the Variance Inflation Factor (VIF) analysis. Generally, if the outcome of the VIF analysis is below 10, it means that the multicollinearity problem does not significantly alter regression results. Although the VIF analysis does not provide a red sign to the researcher, s/he should be aware of that this obvious interdependency between BVE and earnings may yield incorrect inferences.

In this study, we aim to shed light on such incorrect inferences. In this study, we suggest subtracting net income available to owners of parent from BVE before analyses. Without this adjustment, earnings are not found as value relevant which is contrary to expectations. However, by performing this subtraction, we show that earnings are value relevant as expected. To our knowledge, this is the first study revealing deficiencies of the prevalent misleading VR formula, as shown in Equation (1), and it contributes to the literature with the motivation of offering an easy solution to researchers using this Model.

The rest of this paper is structured as follows. The second section presents the critical literature discussion. The third section describes the sample selection and data analyses. The fourth section demonstrates outcomes of our analyses. The last section concludes this study.

\section{Literature Review}

The literature includes blurred outcomes on VR of accounting information as many studies may be flawed or misconstrued (Ball, 2016). Navarro-Garcia and Madrid-Guijarro (2014) state that different sampling criteria, as well as different econometric concerns, may contribute to mixed outcomes. For instance, while Bartov, Goldberg and Kim (2005) find that German Generally Accepted Accounting Principles (GAAP)-based earnings are less value relevant than IAS-based earnings, Hung and Subramanyam's (2007) research documents contrary findings. The sample of Bartov et al. (2005) covers the period over 1991-2000 whereas that of Hung and Subramanyam (2007) includes observations between 1998 and 2002. Among all studies, these two are contentiously selected as they reveal adverse outcomes for the impact of IAS adoption in the same country. Moreover, econometric concerns of researchers may change VR outcomes as illustrated by Ertuğrul and Demir (2018) and Onali, Ginesti and Vasilakis (2017) in detail. ${ }^{1}$ However, we highlight the

\footnotetext{
${ }^{1}$ As the scope of our study is not to question analyses performed by the literature, we do not discuss it further and refer
} the reader to those authors. 
potential and possible contribution of different econometric analyses to below discussed studies providing unexpected outcomes on VR of earnings. In our literature review, we first find studies covering similar periods and samples. In order to make comparison easier, we select studies documenting outcomes by using the number of shares outstanding as it is the most prevalent deflator used in the literature (Ertuğrul, 2019a). Then, we discuss their outcomes.

Studies analysing samples of Turkish listed firms provide mixed outcomes on VR of earnings. By covering the pre-IFRS (2001-2002) adoption and the post-IFRS (2005-2006) adoption periods, Türel (2009) finds that the impact of earnings on share prices is significantly negative in the pre-IFRS adoption period while it turns to be significantly positive in the post-IFRS adoption period. By covering the pre-IFRS (2000-2002) adoption and the post-IFRS (2005-2009) adoption periods, Suadiye (2012) concludes that the impact of earnings on share prices is significantly positive in both periods. By covering the post-IFRS adoption period over 20052011, Akkaya and Aktaş (2013) report that the impact of earnings on share prices is not statistically significant; in other words, earnings are not value relevant. They further reveal that this outcome is not sensitive to size, leverage, and cash flows. By covering the 10-year period beginning from 2000, Sultanoğlu (2014) reveals that earnings are not value relevant for both pre-IFRS adoption and post-IFRS adoption periods. By employing the similar time interval to Sultanoğlu (2014), Cengiz and Tosunoğlu (2017) document that earnings are not value relevant in the pre-IFRS adoption period while they turn to be positively value relevant in the post-IFRS adoption period. By covering the post-IFRS adoption period over 2009-2013, Acar and Karacaer (2017) show that earnings are not value relevant. This outcome belongs to their Price Model regressions. Their Return Model regressions also indicate that the impact of earnings on share returns is significantly negative. By employing a sample over 1998-2011, Karğın (2013) finds that VR of earnings significantly declines after IFRS adoption. Moreover, during the whole post-IFRS adoption period covering 7 years, earnings are reported as value relevant only in 2007 and the association is positive.

Mixed outcomes are not only valid for studies employing Turkish samples. For instance, Devalle, Onali, and Magarini (2010) find that local GAAP-based earnings figures have significantly negative impacts on share prices in the UK. It is a very counterintuitive outcome since the local GAAP in the UK is a typical version of the Anglo-Saxon system which is a fair value-oriented and shareholder-based financial reporting regime (Devalle et al., 2010). However, several studies including Horton and Serafeim (2010), Iatridis (2010) and Clarkson et al. (2011) document a significantly positive association between UK GAAP-based earnings figures and share prices.

We underscore that analysed time intervals, sectoral inclusion/exclusion criteria of samples, and econometrical concerns of researchers including regression settings and standard error clustering techniques considerably affect VR of accounting items. In addition to these, in this study, we shed light on conveniently employing BVE which may contribute to mixed VR inferences.

\section{Methodology}

\section{Sample Selection}

Listed entities on Borsa Istanbul over 2010-2019 is employed in this study. Price data is retrieved from the database of Borsa Istanbul which provides price data for each month-end beginning from 2009. Equation (1) shows a time lag between financial reporting information and market data. Therefore, financial reporting data belongs to the period 2009-2018 and it is retrieved from the Public Disclosure Platform. For each year, the following filtering are performed: i) utilities, financial entities, and holding companies are excluded because they have divergent financial reporting regulations and practices, ii) all watchlist market entities are excluded as their stocks are traded within very short periods each trading day, iii) if there are multiple class stocks, the most liquid class is included, iv) observations with the fiscal year-end except for $31^{\text {st }}$ of December are excluded, v) observations with any missing data are excluded, and vi) non-positive BVE observations are excluded as per problems spring from going-concern. All in all, the final sample includes 294 firms and 2,314 firm-year observations.

\section{Data Analyses}

Before analyses, each variable is winsorized at the top and bottom $1 \%$ to eliminate the overinfluence of outliers. Afterward, we control for multicollinearity by performing the traditional VIF analysis. All VIF 
figures belonging to all Equations are smaller than 10 which should be read as no significant multicollinearity problem affecting our regression outcomes. Note that in Equation (1), BVE includes a significant portion of net income, which is net income available to owners of parent. Hence, the VIF figure belonging to that Equation may be misleading if it yields a figure less than the critical VIF figure of 10. For instance, in our analyses, the VIF figure reported for Equation (1) is 2.20 which should be interpreted as follows: the multicollinearity problem does not influence regression findings at conventional significance levels. Researchers should be aware of the fact that this inference may be incorrect since net income is partially integrated to BVE. From that perspective, we suggest using Equation (2) to researchers:

$\mathrm{P}_{\mathrm{i}, \mathrm{t}+1}=\beta_{0}+\beta_{1} \times \mathrm{Adj}_{-} \mathrm{BVE} \mathrm{i,t}+\beta_{2} \times \mathrm{E}_{\mathrm{i}, \mathrm{t}}$

Except for Adj_BVE, which is BVE adjusted for net income available to owners of parent, all variables are previously described. The literature generally measures price after three and four months from the fiscal year-end (Ertuğrul, 2019a). Therefore, we employ these two price figures to show the robustness of our outcomes. P3 and P4 respectively refer to the former and latter price measurements. All variables are defined in the per-share basis.

The correct regression method is so essential to draw correct VR inferences (Ertuğrul \& Demir, 2018; Onali et al., 2017). At the first step, we perform the Hausman test for each Equation. Since the Hausman Test significantly suggest controlling for endogeneity at the firm-level, we perform fixed-effects regressions. As suggested by Ertuğrul and Demir (2018), we also control for endogeneity at the year-level to reduce the potential bias. Year dummies are not presented in regression tables for the sake of brevity. Last, as perfectly discussed and analysed by Gow, Ormazabal, and Taylor (2010) and Petersen (2009), we use two-way clustered standard errors (at both firm and year levels) to control for the serial correlation and the crosssectional correlation in standard errors.

\section{Results and Discussion}

The first Panel of Table 1 demonstrates major descriptive characteristics of our dataset. The median P3 (P4) is 3.54 (3.64) TL while the median reported BVE is 2.42 TL. Furthermore, the median and mean statistics of earnings indicate that entities are lucrative. Our unreported statistics reveal that approximately $70 \%$ of total observations record profits.

Table 1. Descriptive Statistics and Correlation Matrices.

\begin{tabular}{|c|c|c|c|c|c|c|c|c|}
\hline \multicolumn{9}{|l|}{ PANEL A } \\
\hline & $\mathbf{N}$ & MEAN & P10 & P50 & P90 & SD & MIN & MAX \\
\hline P3 & 2,314 & 13.14 & 0.950 & 3.540 & 29.85 & 29.62 & 0.300 & 190 \\
\hline P4 & 2,314 & 13.91 & 0.990 & 3.640 & 29.36 & 33.18 & 0.290 & 232 \\
\hline BVE & 2,314 & 5.314 & 0.753 & 2.424 & 11.43 & 9.100 & 0.201 & 63.69 \\
\hline E & 2,314 & 0.577 & -0.320 & 0.170 & 1.557 & 1.538 & -1.898 & 9.404 \\
\hline \multicolumn{4}{|l|}{ PANEL B } & & \multicolumn{4}{|l|}{ PANEL C } \\
\hline & P3 & BVE & $E$ & & & P4 & BVE & $E$ \\
\hline P3 & 1 & & & & P4 & 1 & & \\
\hline BVE & $0.8228^{*}$ & 1 & & & BVE & $0.8386^{*}$ & 1 & \\
\hline E & $0.6814^{*}$ & $0.7380^{*}$ & 1 & & E & $0.6808^{*}$ & $0.7380^{*}$ & 1 \\
\hline \multicolumn{4}{|l|}{ PANEL D } & & \multicolumn{4}{|l|}{ PANEL E } \\
\hline & P3 & Adj_BVE & $E$ & & & P4 & Adj_BVE & $E$ \\
\hline P4 & 1 & & & & P4 & 1 & & \\
\hline Adj_BVE & $0.7932^{*}$ & 1 & & & Adj_BVE & $0.8095^{*}$ & 1 & \\
\hline$E$ & $0.6687^{*}$ & $0.6237^{*}$ & 1 & & E & $0.6682^{*}$ & $0.6237^{*}$ & 1 \\
\hline
\end{tabular}

Note: Panel A presents descriptive statistics while other Panels demonstrates correlation matrices. P3 (P4), BVE, Adj_BVE, and E respectively refer to stock price measured after three (four) months from the fiscal year-end, book value of equity, book value of equity adjusted for net income available to owners of parent, and earnings. All variables are deflated by the number of shares outstanding. N, MEAN, P10, P50, P90, SD, MIN, and MAX refer to the total number of observations, mean, $10^{\text {th }}$ percentile, median, $90^{\text {th }}$ percentile, standard deviation, minimum, and maximum. ${ }^{*}$ indicates the significance level at $5 \%$. 
In Panels B and D (C and E) of Table 1, correlation matrices belonging to P3 (P4) are presented. Panels B and $\mathrm{C}$ are obtained for Equation (1) while the last two Panels are obtained for Equation (2). Significantly positive regression coefficients presented in all Panels are in line with common expectations and the extant literature. Furthermore, these correlation matrices indicate the mechanical interdependency between BVE and earnings: the correlation coefficient between earnings and BVE is 0.7380 whereas the correlation coefficient between earnings and adjusted BVE is 0.6237 . Note that the traditional VIF analysis gives no red sign.

The first (second) column of each Panel in Table 2 reveals regression outcomes with the dependent variable of P3 (P4). Panel A of Table 2 reports that the association between BVE and price is significantly positive at conventional levels. Moreover, the same association is reported for adjusted BVE in Panel B of Table 2. These significantly positive regression coefficients robustly indicate that BVE and adjusted BVE significantly affect prices which should be read as clear evidence for VR of BVE figures. These outcomes are also consistent with the extant literature (e.g., Akkaya \& Aktaş, 2013; Ates, 2020; Bilgic, Ho, Hodgson, \& Xiong, 2018; Cengiz \& Tosunoğlu, 2017; Ertuğrul, 2019b, 2020; Ertuğrul \& Demir, 2018; Güleç, 2017; Karğın, 2013; Suadiye, 2012; Sultanoğlu, 2014; Türel, 2009) documenting evidence for Turkish listed firms under the IFRS adoption period.

Table 2. Regression Outcomes for the Whole Sample

\begin{tabular}{|c|c|c|c|c|}
\hline \multirow[b]{2}{*}{ BVE } & \multicolumn{2}{|c|}{ PANEL A } & \multicolumn{2}{|c|}{ PANEL B } \\
\hline & $\begin{array}{c}2.4719^{* * *} \\
(0.0000)\end{array}$ & $\begin{array}{c}2.8758^{* * *} \\
(0.0000)\end{array}$ & & \\
\hline Adj_BVE & & & $\begin{array}{c}2.4943^{* * *} \\
(0.0000)\end{array}$ & $\begin{array}{c}2.8849^{* * *} \\
(0.0000)\end{array}$ \\
\hline E & $\begin{array}{c}0.2305 \\
(0.7136)\end{array}$ & $\begin{array}{c}0.0745 \\
(0.9320)\end{array}$ & $\begin{array}{c}2.8391^{* * *} \\
(0.0006)\end{array}$ & $\begin{array}{c}3.1135^{* * *} \\
(0.0020)\end{array}$ \\
\hline Constant & $\begin{array}{l}-0.1227 \\
(0.9162)\end{array}$ & $\begin{array}{l}-1.4135 \\
(0.3631)\end{array}$ & $\begin{array}{l}-0.1851 \\
(0.8855)\end{array}$ & $\begin{array}{l}-1.4093 \\
(0.3893)\end{array}$ \\
\hline $\begin{array}{l}\text { Observations } \\
\text { R-squared }\end{array}$ & $\begin{array}{l}2,314 \\
0.915\end{array}$ & $\begin{array}{l}2,314 \\
0,913\end{array}$ & $\begin{array}{l}2,329 \\
0.911\end{array}$ & $\begin{array}{l}2,329 \\
0,908\end{array}$ \\
\hline
\end{tabular}

Notes: All variables are defined in the Notes of Table 1. In each column, the first (second) column presents regression outcomes with the dependent variable of P3 (P4). Firm-fixed effects and year-fixed effects are controlled. Two-way clustered standard errors (at both firm and year levels) are used. Parentheses show $\mathrm{p}$-values. ${ }^{* * *} \mathrm{p}<0.01,{ }^{* *} \mathrm{p}<0.05,{ }^{*} \mathrm{p}<0.1$.

In Panel A of Table 2, no regression coefficient of earnings is reported as significant even at the $10 \%$ level. In other words, earnings have no impact on prices, and they are value irrelevant. It does not make sense since this outcome means that recording profits does not influence the firm valuation, and we claim that this outcome springs from the mechanical interdependency between earnings and BVE. We consider that several studies documenting value irrelevant earnings suffer from this problem. As a solution, we suggest researchers employ adjusted BVE figures for net income available to owners of parent. Panel B of Table 2 demonstrates outcomes for this version of BVE. In this Panel, all regression coefficients turn to be positive at conventional significance levels. These outcomes are intuitive and after mitigating the mechanical interdependency, earnings expectedly become value relevant. Furthermore, after adjusting BVE, Table 2 reveals that the regression coefficients of earnings are greater than the regression coefficients of BVE which should be read as follows: earnings play a more influential role in the valuation than BVE.

Among all discussed studies employing Turkish firms, we partially cover analysed periods of Acar and Karacaer (2017) and Karğın (2013), and the value irrelevance of earnings reported in Panel A of Table 2 is consistent with these studies. Since we do not have exact sampling criteria of Acar and Karacaer (2017) and Karğın (2013), our replications will be expected to be very different than their studies. Acar and Karacaer's (2017) period of analysis (2009-2013) is a subset of our dataset; however, i) they use quarterly data, the volatility of which are more than annual earnings (Bandyopadhyay, Chen, \& Wolfe, 2017), and ii) their research employs the Price Model without BVE which is not a familiar VR research setting as it excludes BVE from the model. As the scope of our study is to reveal undetected mechanical interdependency between 
BVE and earnings and the impact of this interdependency on VR inferences, replicating Acar and Karacaer (2017) does not make sense. Moreover, our financial statement information is annual. Although our dataset covers the last three years of Karğın's (2013) period of analysis (2009-2011), she documents evidence for VR of accounting items for each year by performing cross-sectional analyses and she reports that earnings are not value relevant for each of these three years. Observations of Karğın (2013) belonging to 2009, 2010, and 2011 is 137, 139, and 146 while our observations belonging to these years are 193, 207, and 227. On average, our sample size is almost 50\% of Karğın's (2013) sample size belonging to these years. Therefore, our samples are not comparable. In any case, our untabulated panel regressions for the period over 2009-2011 confirm outcomes reported in Table $2 .^{2}$

Table 3. Regression Outcomes for the Profit Sample

\begin{tabular}{lccccc}
\hline & \multicolumn{2}{c}{ PANEL A } & & \multicolumn{2}{c}{ PANEL B } \\
\cline { 2 - 3 } \cline { 5 - 6 } BVE & $2.2043^{* * *}$ & $2.5762^{* * *}$ & & \\
Adj_BVE & $(0.0000)$ & $(0.0000)$ & & $2.1804^{* * *}$ & $2.5451^{* * *}$ \\
& & & & $(0.0000)$ & $(0.0000)$ \\
E & & & & $4.0940^{* * *}$ & $4.5636^{* * *}$ \\
& 1.6604 & 1.7166 & & $(0.0000)$ & $(0.0008)$ \\
Constant & $(0.1149)$ & $(0.2481)$ & & 0.2289 & -1.2153 \\
& 0.2226 & -1.2315 & & $(0.8807)$ & $(0.5768)$ \\
& $(0.8816)$ & $(0.5760)$ & & 1,632 & 1,632 \\
Observations & 1,639 & 1,639 & & 0.9228 & 0.9211 \\
R-squared & 0.9265 & 0.9253 & & & \\
\hline
\end{tabular}

Notes: All variables are defined in the Notes of Table 1. In each column, the first (second) column presents regression outcomes with the dependent variable of P3 (P4). Firm-fixed effects and year-fixed effects are controlled. Two-way clustered standard errors (at both firm and year levels) are used. Parentheses show $p$-values. ${ }^{* *} p<0.01,{ }^{* *} p<0.05,{ }^{*} p<0.1$.

As price-earnings relation are different in profit and loss observations (Hayn, 1995), we exclude loss observations (as in Gómez-Rodríguez, Muiño, \& Lamas, 2012; Karğın, 2013) to check whether our outcomes are driven by loss observations. Therefore, we perform an additional analysis to a sample of profit-recording observations and present these outcomes in Table 3. Again, no regression coefficient of earnings in Panel A of Table 3 is reported as statistically significant which indicates the value irrelevance of earnings. In other words, these results generate the following incorrect inference: share prices remain unaffected although a firm announces a profit figure. After correcting BVE for net income available to owners of parent, this incorrect inference is not valid since earnings become statistically significant; and hence, value relevant.

\section{Conclusion}

In this study, we analyse how the mechanical interdependency between independent variables generates incorrect VR inferences by considering the Price Model of Ohlson (1995). Independent variables of this Model are earnings and BVE, and earnings are partially integrated to BVE via the net income available to owners of parent item. Therefore, the Price Model with the unadjusted (or reported) version BVE may yield incorrect VR outcomes. Although the VIF outcome does not indicate any significant multicollinearity problem, researchers should be aware of this integration and mitigate it before analyses. Our study sheds light on the mechanical interdependency between independent variables in VR research which is not detected by the VIF analysis and suggests an adjustment to perform VR analyses generating correct inferences. This is the major contribution of our paper to VR research.

Our study suggests researchers subtract net income available to owners of parent from BVE prior to analyses. We compare VR of accounting items obtained by employing the Price Model with the unadjusted (or reported) version BVE and the Price Model with the adjusted version of BVE. All research settings conclude that BVE is value relevant. However, earnings are reported as value irrelevant in the Model with

\footnotetext{
${ }^{2}$ Results are available from the authors upon request.
} 
the unadjusted version of BVE. After BVE is adjusted for net income available to owners of parent, earnings become value relevant. Our study further reveals that this outcome is not sensitive to influence of loss observations which should be read as the robustness of our findings. Last, after adjusting BVE for net income available to owners of parent, earnings become more dominant than BVE in the valuation.

Since we do not have their exact sampling criteria and covered periods, we do have no opportunity to replicate any discussed studies in the Literature Review section. This is the major caveat of our study. However, our outcomes may indicate that inconsistent VR outcomes of earnings reported by the discussed studies may spring from the mechanical interdependency between earnings and BVE via the net income available to owners of parent item. Future research should perform VR analyses by considering our suggestion of adjusting BVE for this item. At least, our suggestion may be considered a kind of a robustness check by future research.

\section{References}

Acar, M., \& Karacaer, S. (2017). Comparing the Usefulness of Net Income Versus Comprehensive Income in Terms of Firm Performance: Borsa Istanbul Case. International Review of Economics and Management, 5(4), 97-118. https://doi.org/10.18825/iremjournal.328968

Akkaya, B., \& Aktaş, H. (2013). Muhasebe Bilgilerinin Değer İlişkisinde Firmalara Özgü Faktörlerin Etkisi. Atatürk Üniversitesi Sosyal Bilimler Enstitüsü Dergisi, 17(3), 313-326. Retrieved from https://dergipark.org.tr/tr/pub/ataunisosbil/issue/2834/38599

Ates, S. (2020). Membership of sustainability index in an emerging market: Implications for sustainability. Journal of Cleaner Production, 250, 119465. https://doi.org/10.1016/j.jclepro.2019.119465

Ball, R. (2016). IFRS - 10 years later. Accounting and Business Research, 46(5), 545-571. https://doi.org/10.1080/00014788.2016.1182710

Ball, R., \& Brown, P. (1968). An Empirical Evaluation of Accounting Income Numbers. Journal of Accounting Research, 6(2), 159-178. https://doi.org/10.2307/2490232

Bandyopadhyay, S. P., Chen, C., \& Wolfe, M. (2017). The predictive ability of investment property fair value adjustments under IFRS and the role of accounting conservatism. Advances in Accounting, 38, 1-14. https://doi.org/10.1016/j.adiac.2017.05.002

Barth, M. E., Beaver, W. H., \& Landsman, W. R. (2001). The relevance of the value relevance literature for financial accounting standard setting: another view. Journal of Accounting and Economics, 31(1-3), 77104. https://doi.org/10.1016/S0165-4101(01)00019-2

Bartov, E., Goldberg, S. R., \& Kim, M. (2005). Comparative Value Relevance Among German, U.S., and International Accounting Standards: A German Stock Market Perspective. Journal of Accounting, Auditing \& Finance, 20(2), 95-119. https://doi.org/10.1177/0148558X0502000201

Beaver, W. H. (1968). The Information Content of Annual Announcements Earnings. Journal of Accounting Research, 6(3), 67-92. https://doi.org/10.2307/2490070

Beaver, W. H. (2002). Perspectives on Recent Capital Market Research. Accounting Review, 77(2), 453-474. https://doi.org/10.2308/accr.2002.77.2.453

Bilgic, F. A., Ho, S., Hodgson, A., \& Xiong, Z. (2018). Do Macro-economic Crises Determine Accounting Value Relevance? Accounting in Europe, 15(3), 402-422. https://doi.org/10.1080/17449480.2018.1514123

Brown, S., Lo, K., \& Lys, T. (1999). Use of R2 in accounting research: measuring changes in value relevance over the last four decades. Journal of Accounting and Economics, 28(2), 83-115. https://doi.org/10.1016/S0165-4101(99)00023-3

Burgstahler, D. C., \& Dichev, I. D. (1997). Earnings, Adaptation and Equity Value. The Accounting Review, 72(2), 187-215. Retrieved from https://www.jstor.org/stable/248552

Cengiz, S., \& Tosunoğlu, B. (2017). Uluslararası Finansal Raporlama Standartlarının Finansal Raporlama Kalitesi Üzerindeki Etkisine Yönelik Bir Araştırma. Atatürk Üniversitesi İktisadi ve İdari Bilimler 
Dergisi, 31(5), 1201-1219. Retrieved from https://dergipark.org.tr/tr/download/issue-full-file/31488

Clarkson, P., Hanna, J. D., Richardson, G. D., \& Thompson, R. (2011). The impact of IFRS adoption on the value relevance of book value and earnings. Journal of Contemporary Accounting and Economics, 7(1), 1-17. https://doi.org/10.1016/j.jcae.2011.03.001

Devalle, A., Onali, E., \& Magarini, R. (2010). Assessing the value relevance of accounting data after IFRS introduction in Europe. Journal of International Financial Management and Accounting, 21(2), 85-119. https://doi.org/10.1111/j.1467-646X.2010.01037.x

Easton, P. D. (1999). Security Returns and the Value-Relevance of Accounting Data. Accounting Horizons, 13(4), 399-412. https://doi.org/10.2308/acch.1999.13.4.399

Easton, P. D., \& Harris, T. S. (1991). Earnings as an Explanatory Variable for Returns. Journal of Accounting Research, 29(1), 19-36. https://doi.org/10.2307/2491026

Easton, P. D., Harris, T. S., \& Ohlson, J. A. (1992). Aggregate accounting earnings can explain most of security returns: The case of long return intervals. Journal of Accounting and Economics, 15(2-3), 119142. https://doi.org/10.1016/0165-4101(92)90015-T

Ertuğrul, M. (2019a). A Review of the Literature on IFRS Adoption From the Perspective of the Value Relevance. In H. Dincer \& S. Yüksel (Eds.), Handbook of Research on Global Issues in Financial Communication and Investment Decision Making (pp. 367-394). https://doi.org/10.4018/978-1-5225-92655.ch017

Ertuğrul, M. (2019b). Interpretation of the Value Relevance Indicator With(out) Dummies: Demeaning. In H. Dincer \& S. Yüksel (Eds.), Handbook of Research on Global Issues in Financial Communication and Investment Decision Making (pp. 192-213). https://doi.org/10.4018/978-1-5225-9265-5.ch010

Ertuğrul, M. (2020). Maddi Olmayan Duran Varlıkların Değer İlişkisi. Muhasebe ve Denetime Bakış, 59, 213233. Retrieved from https://www.turmob.org.tr/ekutuphane/detailPdf/c3e5e05c-b02b-4434-960d8c584fed643b/muhasebe-ve-denetime-bakis-dergisi-sayi-59

Ertuğrul, M., \& Demir, V. (2018). How Does Unobserved Heterogeneity Affect Value Relevance? Australian Accounting Review, 28(2), 288-301. https://doi.org/10.1111/auar.12228

Francis, J., \& Schipper, K. (1999). Have Financial Statements Lost Their Relevance? Journal of Accounting Research, 37(2), 319-352. https://doi.org/10.2307/2491412

Gómez-Rodríguez, L. M., Muiño, F., \& Lamas, F. R. (2012). Do investing cash flows help in explaining future corporate performance? Spanish Journal of Finance and Accounting / Revista Española de Financiación y Contabilidad, 41(154), 185-208. https://doi.org/10.1080/02102412.2012.10779722

Gow, I. D., Ormazabal, G., \& Taylor, D. J. (2010). Correcting for Cross-Sectional and Time-Series Dependence in Accounting Research. Accounting Review, 85(2), 483-512. https://doi.org/10.2308/accr.2010.85.2.483

Güleç, Ö. F. (2017). Nakit akışları ve kazançların değer ilişkisi: Borsa İstanbul uygulaması. Muhasebe Bilim Dünyast Dergisi, 19(2), 524-546. Retrieved from https://dergipark.org.tr/tr/pub/mbdd/issue/54663/746101

Hayn, C. (1995). The information content of losses. Journal of Accounting and Economics, 20, 125-153. https://doi.org/10.1016/0165-4101(95)00397-2

Horton, J., \& Serafeim, G. (2010). Market reaction to and valuation of IFRS reconciliation adjustments: first evidence from the UK. Review of Accounting Studies, 15(4), 725-751. https://doi.org/10.1007/s11142009-9108-5

Hung, M., \& Subramanyam, K. R. R. (2007). Financial statement effects of adopting international accounting standards: The case of Germany. Review of Accounting Studies, 12(4), 623-657. https://doi.org/10.1007/s11142-007-9049-9

Iatridis, G. (2010). International Financial Reporting Standards and the quality of financial statement information. International Review of Financial Analysis, 19(3), 193-204. 
https://doi.org/10.1016/j.irfa.2010.02.004

Karğın, S. (2013). The Impact of IFRS on the Value Relevance of Accounting Information: Evidence from Turkish Firms. International Journal of Economics and Finance, 5(4), 71-80. https://doi.org/10.5539/ijef.v5n4p71

Kothari, S. P. (2001). Capital Markets Research in Accounting. Journal of Accounting and Economics, 31, 105231. https://doi.org/10.1016/S0165-4101(01)00030-1

Kothari, S. P., \& Zimmerman, J. L. (1995). Price and return models. Journal of Accounting and Economics, 20(2), 155-192. https://doi.org/10.1016/0165-4101(95)00399-4

Miller, M. H., \& Modigliani, F. (1966). Some Estimates of the Cost of Capital to the Electric Utility Industry, 1954-1957. The American Economic Review, 56(3), 333-391. Retrieved from http://www.jstor.org/stable/1823774

Navarro-García, J. C., \& Madrid-Guijarro, A. (2014). The Influence of Improvements in Accounting Standards on Earnings Management: The Case of IFRS. Australian Accounting Review, 24(2), 154-170. https://doi.org/10.1111/auar.12020

Ohlson, J. A. (1995). Earnings, Book Values, and Dividends in Equity Valuation. Contemporary Accounting Research, 11(2), 661-687. https://doi.org/10.1111/j.1911-3846.1995.tb00461.x

Onali, E., Ginesti, G., \& Vasilakis, C. (2017). How should we estimate value-relevance models? Insights from European data. British Accounting Review, 49(5), 460-473. https://doi.org/10.1016/j.bar.2017.05.006

Petersen, M. A. (2009). Estimating standard errors in finance panel data sets: Comparing approaches. Review of Financial Studies, 22(1), 435-480. https://doi.org/10.1093/rfs/hhn053

Suadiye, G. (2012). Value Relevance of Book Value \& Earnings Under the Local GAAP and IFRS: Evidence from Turkey. Ege Akademik Bakış, 12(3), 301-310. Retrieved from https://dergipark.org.tr/en/pub/eab/issue/39900/473735

Sultanoğlu, B. (2014). UFRS'nin Borsa İstanbul'daki Şirketlerin Finansal Tabloları Üzerindeki Etkisi: Finansal Bilginin İhtiyaca Uygunluğu Ve Finansal Tablolar Analizi (Unpublished PhD Thesis). Başkent University.

Türel, A. (2009). The Value Relevance of IFRS: The Case of Turkey. Acta Universitatis Danubius. CEconomica, 5(1), 119-128. Retrieved from http://journals.univdanubius.ro/index.php/oeconomica/article/view/81 